\title{
Redeeming Woman: A Response to the "Second Sex" Issue from within the Tradition of Catholic Scriptural Exegesis
}

\section{Deborah Savage}

St. Paul Seminary, University of St. Thomas, St Paul, MN 55105, USA; pdsavage@stthomas.edu

Received: 11 June 2020; Accepted: 14 September 2020; Published: 17 September 2020

\begin{abstract}
The aim of this paper is to correct an historical error: the ancient claim, grounded in a flawed understanding of the reproductive act, that woman is inferior to man. I will show that the lineage of this can be traced as far back as the pre-Socratic philosophers, finally finding its earliest concrete expression in a claim most have either dismissed, forgotten, or never heard: Aristotle's argument that women are merely "malformed males" and are therefore "inferior to man." The theory found support in the first century with a historical interpretation of Genesis 2:18-23, traceable in particular to the Hellenistic Jewish philosopher, Philo (BC 13-AD 54). Philo's own theory about woman echoed that of Aristotle's; his legacy includes the vague feeling that Scripture itself declares that, since woman is created after man, she is necessarily subservient to him. She becomes, as it were, the "second sex." I dispute both these accounts and show that they can be defeated on their own terms. Through the lens of Hebraic and Aristotelian-Thomistic anthropology, and building on the insights of St. John Paul II, I provide a robust, philosophically and theologically grounded account of man and woman from within the Catholic exegetical tradition.
\end{abstract}

Keywords: feminism; woman; genesis; creation; equality; difference

"The least initial deviation from the truth is multiplied later a thousand-fold." Aristotle, De Caelo, I, 5

\section{Introduction}

Feminism is an intellectual tradition as well as a social movement and as such it has many different streams and tributaries, commonly referred to as "waves". Treatments of this tradition and movement typically distinguish between the intellectual foundations and the political projects of some four such "waves". Though it is impossible in the space of one paper to offer a Catholic theological engagement with the presuppositions of each these streams, tributaries, and waves, it is possible to discern an element common to each of them: The concern, famously articulated by Simone de Beauvoir, that women are treated as the "second sex". For many feminists, this state of affairs can be traced to a particular reading of the book of Genesis. A less obvious but arguably even more problematic factor is the provenance of that interpretation: The flawed account of woman introduced into the western intellectual tradition by another ancient source, the thought of Aristotle.

The aim of this paper is therefore to identify the sources of the "second sex" mentality, and to offer a correction to it. The correction will necessarily involve an engagement with the book of Genesis. In particular, it will require an analysis of God's purpose in creating the human species in male and female forms. While the proposed correction will not answer all feminist criticisms of the Catholic theological tradition, especially those of the later waves that view masculinity and femininity as mere social constructs, it is hoped that the paper will at least offer a corrective to elements of the Catholic theological tradition that have been complicit in the promotion of the "second sex" mentality and contributed thereby to numerous social pathologies and feminist grievances. It is also hoped that this 
corrective might at least assuage some of the concerns that feminists have with the Catholic intellectual tradition and Christianity more generally.

Central to the 'corrective' is the argument that neither woman nor man, properly considered, are normative for the species. They are equally human since both are instantiations of the same substantial form, a rational soul, and equipped with the same rational powers, both possessing in equal measure intellect, will, and freedom. However, they are also manifestly different: Complementary expressions of the same human nature, both occupying, each in their own way, a certain pride of place in the created order. Both of these premises will be demonstrated in this paper. In fact, they will be derived from the very same theological and philosophical tradition on which Catholic teaching rests. However, the stakes go beyond the intellectual merits of the argument. For as St. John Paul II declared, it is this "complementarity" that constitutes the very mission of man and woman, which is to create, not only human families, but human history itself. ${ }^{1}$ The future of humanity may depend on getting this right.

\section{Diagnosing the Problem: The Historical Trajectory}

The lineage of the "second sex" assumption, at least in the Western intellectual tradition, is buried deep in its history. It can be traced as far back as the pre-Socratic philosophers, finally finding its earliest concrete expression in a claim most have either dismissed, forgotten, or never heard: Aristotle's argument that women are merely "malformed males" and are therefore "inferior to man." 2 On this account, man (qua male) represents the prime analogue of what it is to be human. Aristotle's claim that woman is merely a "malformed male" gained powerful traction through the introduction of an arguably flawed historical interpretation of Genesis 2:18-23, traceable in particular to the Hellenistic Jewish philosopher, Philo (BC 13-AD 54).

Philo's own theory about woman echoed that of Aristotle's and influenced his reading of Genesis; his legacy includes what became an exegetical premise and an assumption that Scripture itself declares that, since woman is created after man, she is necessarily subservient to him. ${ }^{3}$ Philo's thought was highly influential in the early Christian experience. His interpretation of the Biblical creation accounts shaped subsequent understandings of these texts, providing the underpinnings of the historical understanding of woman's place in the created order.

The influence of both Aristotle and Philo in this regard has been well tracked by Sr. Mary Prudence Allen, R.S.M., whose three-volume series, The Concept of Woman, traces the development of thought on the question of man-]woman relations from the pre-Socratic era up to the present day.

\subsection{Assessing Theories on Man-Woman Relations: A Primer}

Sr. Allen's exhaustive investigation reveals that philosophical reflection on the concept of woman in relation to man has been an aspect of our intellectual tradition since at least 750 BC; it arose as a subject of inquiry as soon as the earliest philosophers considered the question of human identity. She traces the work of these early thinkers and points out that, though none of them developed a systematic account of woman in relation to man, they did open up the question in significant ways, making distinctions that remain relevant even in the present day.

\section{(John 1995, p. 8).}

(Aristotle 1943, 716a, pp. 9-17). Arguably one should not reject Aristotle's entire achievement as a result of this error, any more than throw out his legacy because he argued that the earth was at the center of the universe. Clearly, later generations of scholars stand on his shoulders in terms of his larger anthropological framework, as well as his ground-breaking advances in science and biology, in metaphysics, political theory, and ethics.

3 (Aristotle 1943, 765a, 20); Cited also by (Allen 1985, pp. 87-99, 193). See also (Philo 1929-1962, Bk I, chp. 27, 16). Philo's theory reflects the same conclusion, viz., that woman is not equal to man. However, Philo was also an important first century theologian who interpreted the creation of woman in Genesis 2 through the lens of his philosophical conclusions. Philo's account merged with Aristotle's theory, adding a theological thrust to his influence on the development of the concept of woman in Christian thought. 
Sr. Allen concludes that their questions on the subject seem to fall into four broad categories: "How are male and female opposite? What is the relation between sex identity and generation? Are women and men wise in the same or different ways? Are women and men virtuous in the same or different ways?"4 She draws a very helpful correlation between these questions and four fundamental philosophical disciplines: Metaphysics (opposites); philosophy of science (generation); epistemology (wisdom); and ethics and politics (virtue)..$^{5}$ This schema serves as a sort of template throughout her entire investigation; it allows for a systematic evaluation of the many theories of sex identity and man-woman relations illuminated by her study. ${ }^{6}$

Sr. Allen maintains that, at a minimum, every such theory must be evaluated in light of how it accounts for two fundamental principles of gender relations: Equal dignity and significant difference. ${ }^{7}$ In other words, every theory purporting to explain man and woman must account both for their equality and for what distinguishes them. She argues that when either of these two principles is ill-defined or missing from any particular account of gender relations, it falls inevitably into either a form of "gender polarity" theory, where one sex is considered superior to the other, or into a form of "unisex" theory, which denies any significant differentiation between them. Versions of both theories have circulated in one way or another from the start of the western philosophical tradition-with one or the other achieving prominence in various periods of history. Both persist in contemporary accounts of gender relations. Neither serve woman well. ${ }^{8}$

Aristotle's own thinking on the subject begins with a critique of previous philosophers, especially Plato, who was the first to offer any kind of systematic account of the man-woman relation. Plato is the founder of what Sister Prudence has termed the unisex theory; that is, he argued that there was no significant difference between men and women while insisting on their basic equality. It is worth noting that Greek society at the time was structured around a sex-polarity model; men and women were different from each other, and men were simply assumed to be superior to women. However, Plato's own theory of the soul led him to depart from that position. He argued that the differences between men and women were not important and that man and woman were basically interchangeable. ${ }^{9}$

Aristotle explicitly rejected many of the theories suggested before him and disputed Plato's account in particular. In opposition to Plato's unisex theory, Aristotle is the founder of traditional gender polarity. That is, he argued unequivocally that man is superior to woman, that the male of the species is the prime instance of man qua man, and that the female is a "privation" of the male. That is, she is lacking powers that properly belong to human nature per se, and therefore is inferior to man since he possesses the full range of powers that constitute what it means to be human. This claim obviously requires further elaboration and we will return to it in a moment. However, there can be no question that Aristotle's description of the female as the privation of the male came to dominate the whole history of western philosophy; it provides the starting place for the definitive account of the metaphysical framework of sex polarity.

4 (Allen 1985, p. 75). The author is aware that there is debate about the connection between gender and sexual identity and the body. In this paper, gender and sex are generally used interchangeably to refer to the sex "assigned at birth," the usage currently advocated in some circles. The former is the usage accepted by Allen in her trilogy.

5 (Allen 1985, pp. 75-76).

6 Her investigation shows that for any theory to be complete, it will have to treat each of them in some way-and that every historical theory has done so. Each has had implications for the development of the concept of woman.

7 (Allen 2006, pp. 87-108).

8 The reflections here have been limited to these two principles. Sr. Allen further distinguishes "traditional" gender polarity from "reverse" gender polarity. The first is the theory that man is superior to woman; founded by Aristotle, it has a longer history. The latter is the theory that woman is superior to man. This idea has surfaced from time to time throughout history; some contemporary feminists and others appear to be advocates for it now. See (Melvin Konner 2015). Sr. Allen also points to two other possibilities: "fractional complementarity," a view in which men and women are both incomplete and constitute one human being only when taken together; this is often found in Protestant interpretations of the biblical text. Last, there is "integral complementarity", which militates against all of these other positions. Sr. Allen argues that this is the properly Catholic position: In integral complementarity, both men and women are equally and fully human and their union is only possible because of their differences. It results in a free, mutual exchange and often a new creation.

9 See (Plato 1961, 453a-454e). 
Aristotle's point of departure is both biological and metaphysical, though he extends his theory to include responses to all four of the questions articulated above. We will consider each of them but will focus on his conclusions to just the first two: "How are male and female opposite? What is the relation between sex identity and generation?" His responses to these two questions will provide the bases for his conclusions to the last two questions: Woman's capacity for wisdom and for virtue.

\subsection{Aristotle on Male and Female}

Aristotle's metaphysical treatment of sex identity is complex, reflecting a synthesis of several interlocking elements. It begins with the category of opposites and his theory of contrariety. This framework also permits him to account for a critical element in his theory of generation. ${ }^{10}$ The principles that serve as the basis for his sex polarity theory are deduced from his conclusions in both categories. A brief sketch of the essential framework follows.

First, along with many of his predecessors, Aristotle argued that there were two pairs of primary opposites: Cold and hot, moist and dry. The interaction of these primary opposites was understood to result in the four elements of fire, air, water, and earth. ${ }^{11}$ We need not linger over those distinctions. The pair of most interest to us here will be that of "cold" and "hot."

Now in Aristotle's account, in any pair of contraries, one is always in some sense a "privation" of the other. By definition, a privation is not a simple negation but refers to the lack of a quality or form normally required by the nature of a thing. That is, one side of the pair is "prime"; the other is defined by a lack of something required by the nature of the thing itself. ${ }^{12}$ Privation is complete nonbeing, with no identity of its own; it will only exist in reference to something that has a nature. ${ }^{13}$ However, it lacks that which the prime instance possesses. For example, in our pair of contraries "hot and cold," cold is defined in relation to heat; it is the privation (absence) of heat. This example gives us a starting place with which to understand Aristotle's account of sex identity and the basis of his arguments concerning the superiority of the male.

Aristotle argues that man and woman are in the same genus and species but that they are "contraries" within the species. ${ }^{14}$ Since, as he claims, in every pair of contraries, one is prime and the other is a privation of that which the prime possesses, this also must be the case with man and woman. It is this reasoning that leads him to conclude that woman is a "privation" of the male, that is, she is without human characteristics that, as a member of the species, she ought to possess. Thus, she is a "malformed male." ${ }^{15}$ In Aristotle's mind, this conclusion is directly supported, indeed "validated," by his theory of generation.

It was common in Aristotle's time to declare that the male of the species possesses greater heat than the female, actually an observable empirical fact. ${ }^{16}$ Aristotle found in this biological "fact" - that the male possessed more heat than the female-clear evidence of the superiority of the male, arguing his greater heat is a constant and represents a "superior value" in reference to the relative coldness of the female. It is his theory of generation that leads him to this conclusion.

Aristotle argues that the male's blood-and therefore his seed-is different from that of the female since it undergoes a process of purification only possible in the male due to his greater heat. He further declares that it is the presence of heat in the male seed that is the cause of the male's fertility. ${ }^{17}$ Though

10 Indeed, he himself makes the connection for us in the Metaphysics as he unfolds his theory of contrariety. At the end of his basic explication of contrariety, he states: "This is why the same seed becomes female or male by being acted on in a certain way." (Aristotle 1941, Bk X, 9, 22-23: 1058-59). We will come to understand his meaning in what follows.

11 (Allen 1985, pp. 93-94).

12 (Aristotle 1941, Bk IX, 1004b, 27).

3 Ibid., Bk X, 1055-1056. See also, (Allen 1985, p. 91).

Aristotle's account of contraries is laid out in the Metaphysics. See (Aristotle 1941, especially Bk X, 4).

(Aristotle 1943, 716a, pp. 9-17).

16 In a 2015 study, Dutch scientists found that women are more comfortable at a room temperature of 75-76 degrees Fahrenheit, whereas men prefer the temperature be around 72 degrees. See (Kingma and van Marken Lichtenbelt 2015).

17 (Allen 1985, pp. 95-96). 
previous accounts of generation had maintained the presence of a female seed, Aristotle rejected them. He argued that the coldness of the female made her infertile, stating elsewhere that the female "lacks the power to concoct semen out of the final state of nourishment because of the coldness of its nature." 18 The male is characterized by the ability to "cause to take shape, and to discharge semen possessing the principle of the form ... [while] female is that which receives the semen but is unable to cause semen to take shape or to discharge it." ${ }^{19}$ She provides only the material on which the heat of the male seed acts. ${ }^{20}$ Thus in the generative act, man provides the form; woman provides the matter.

As the reader is no doubt aware, these conclusions are themselves further grounded in Aristotle's theory of hylomorphism. ${ }^{21}$ Fundamental to that theory are the principles of form and matter: It is the form that makes the thing what it is by actualizing the potency inherent in the matter to become an individual embodiment of the nature of the thing itself. Since without the form, matter is merely passive, matter is understood to be the privation of form. Thus, form is the active principle; it acts on the matter. Matter is the passive principle; it "receives" the form. Form is active; matter is passive. As we have already stipulated, Aristotle's theory of generation leads him to conclude that man supplies the form, woman the matter. Therefore, inevitably, man is active and woman is passive. ${ }^{22}$

Taken together, Aristotle's theory of generation, and of contrariety, grounded as it is in the hylomorphic theory of composite substances thus can lead to only one conclusion: Man is the prime instantiation of the species; woman is defined by lack. She is a derivative and incomplete instantiation of the species humanum. ${ }^{23}$ She is a "malformed male."

This brief summary has provided a sketch of Aristotle's responses to the first two questions mentioned earlier. His conclusions to the last two questions (Are women and men wise in the same or different ways? Are women and men virtuous in the same or different ways?) will come as no surprise. They follow quite logically from his previous deductions. Aristotle argues that, though women have the same kind of reason as men, since the higher reason has no authority over the lower, irrational powers in woman, her reasoning ability is necessarily inferior to that of man. Woman can form true opinions but cannot possess wisdom. ${ }^{24}$ With regard to virtue, woman can possess specifically womanly virtue but cannot be virtuous in the same way a man is. Also, since woman is by nature passive, she cannot be judged by the same criteria as man. Her virtue is to obey, man's is to rule. A woman finds virtue, not in being clever, but in finding a clever man to obey. ${ }^{25}$

Such claims sound outrageous to modern ears; they have no place in our understanding of man and woman. Aristotle's conclusions regarding woman in relation to man are ruled out of court by both sound reason and subsequent developments in scientific knowledge. While we can acknowledge the fact that he is operating with faulty premises, derived from the "scientific" account of generation on offer at the time, (as well as those that reflect the prejudices of the era), there is no doubt that Aristotle's convictions concerning the nature of woman in relation to man provided a starting place for the work of subsequent philosophers on questions of sex identity. ${ }^{26}$ His undeniably disastrous account of sex

\footnotetext{
8 (Aristotle 1937, 728a, p. 1327). Also quoted in (Allen 1985, p. 97).

(Aristotle 1937, 765b, pp. 10-18). Also quoted in (Allen 1985, p. 97)

(Aristotle 1937, 641b). Also quoted in (Allen 1985, p. 91).

21 Though its validity has been questioned by some, it provides a very reasonable and coherent account of both living and non-living substances as well as a point of departure for many other important metaphysical conclusions. It is not under dispute here. It is his application of this theory to the nature of woman in relation to man, informed as it is by his account of contrariety as well as of generation, that is problematic.

22 The notion that matter is pure receptivity or passivity was introduced by Plato. One of Aristotle's most important contributions to the history of philosophy was to argue that matter was not merely passive as in inert; he argued that it possesses a potency in relation to act.

23 (Allen 1985, pp. 92-93).

24 (Allen 1985, pp. 103-4).

25 (Allen 1985, pp. 111-11).

26 (Allen 2002, p. 65).
} 
polarity left what Sr. Allen describes as a "wound" in the western philosophical tradition, disfiguring thought on the concept of woman and shaping the intellectual currents that followed in his wake. ${ }^{27}$

However, it is also true that Aristotle is not the only one responsible for the persistence of the latent sex polarity theory we still encounter today. The impact of Aristotle's work was accelerated by an interpretation of Scripture quite friendly to his account.

\subsection{The Critical Influence of Philo}

We have seen how Aristotle's understanding of the act of generation proved fatal for his account of the nature of woman in relation to man; it can be said to be the starting place of his sex polarity theory. This error would persist for centuries, informing the thinking of many of Aristotle's philosophical heirs. However, it also makes an appearance in the thought of a very influential student of the Platonic tradition, the first century thinker, Philo of Alexandria. It was Philo who introduced the theory of sex polarity into the interpretation of Scripture, thereby multiplying its impact in the trajectory of the western intellectual tradition.

Philo of Alexandria (13 BC-54 AD) was a Hellenistic Jew and a contemporary of Jesus and of St. Paul. His significance as both a philosopher and a theologian is well established; he was one of the most important Jewish authors of the period. ${ }^{28}$ Virtually unknown in the Jewish tradition after his own time, his writings were preserved primarily by the early Christian church. ${ }^{29}$ His work has been important for both the study of Hellenistic philosophy and for understanding the many currents and interpretative traditions of Second Temple Judaism. Philo is also a critical source for any investigation of the early Christian church and New Testament writings. Perhaps most notably, his use of allegorical method as a way of interpreting Scripture was adopted by the early Greek theologian, Clement of Alexandria (d. 215), and led his most famous pupil, Origen, to incorporate it into his three-fold system of interpretation; this system served as a model well into the medieval period and is still relied on today. ${ }^{30}$

However, perhaps the most important contribution Philo made in the history of biblical interpretation was his general exegetical method. He saw no reason to make any kind of artificial separation between revealed truth and that discovered through reason; his method was grounded in his conviction that the philosopher is to apply reason to exegesis in his quest to discover the meaning of reality. His unshakable faith in the truth of revelation itself actually led him to establish a new form of philosophy "in which the revealed truths of scripture became the first principles of a new Greek philosophical tradition." ${ }^{31}$ Philo's significance is indisputable, extending well beyond our concerns in this paper.

Philo wrote many philosophical and theological texts, though he devoted most of his attention to his main interest: Illuminating the hidden meaning of the Torah (the first five books of the Bible). This search was driven by his own desire to deepen his understanding of the God of Moses. The Hellenist culture in which Philo lived was fertile ground, providing rich and deep resources for interpreting the Biblical texts, an aim he pursued through the interpretive lens provided by his deep understanding of the Platonic philosophical tradition. We will focus our attention on one particular text, his Questions and Answers on Genesis. ${ }^{32}$ It is here that we find his theory of sex polarity and his interpretation of Genesis 2, our main interest.

\footnotetext{
(Allen 2002, p. 65).

(Scholer 1993, p. xi).

(Scholer 1993, p. xiii).

30 Origen's system of interpretation had three levels. It began with the literal (plain) meaning of the text, proceeded to its moral meaning, and finally to the spiritual or allegorical. This system was taken up by medieval theologians, including St. Thomas Aquinas, who added a fourth level, that of the analogical.

31 (Cortest 2017, p. 9).

32 (Philo 1929-1962). Quoted also in (Allen 1985, pp. 189-93).
} 
Philo's primarily Platonic outlook might lead one to assume that his theory of sex identity would correspond more closely to the unisex account advanced by Plato. However, instead, Philo constructed a theory of sex polarity remarkably similar to that of Aristotle's. Philo does not refer to Aristotle in his writings; there are differing opinions on how much influence Aristotle had on him and what the source of that influence might have been. ${ }^{33}$ Whatever the source, Philo's account mirrored Aristotle's in almost every way, including its starting place in a similar understanding of woman's role in the act of generation. Without question, Philo's writings would be relied on by many future scholars as support for the Aristotelian concept of woman. ${ }^{34}$

Though Philo's own theory has some interesting nuances, it will not be necessary to provide a detailed description here; it would mean simply repeating much of what we have already learned about the Aristotelian account, at least in its conclusions. However, unlike his philosophical forbears, Philo developed a theory of sex polarity from two distinct but, for him, intertwined sources: Philosophy and reason, and revelation.

The conclusions Philo reached through philosophy and reason are, at least in principle, based in science. Since he labored under the same flawed scientific assumptions found in the earlier philosophical traditions, that woman's contribution to the act of generation was a passive one, we easily recognize his conclusions from this first source. He declares that "the matter of the female ... produces the foetus ... but the man provides the skill and the cause ... the male provides the greater and more necessary part." ${ }^{\prime 35}$ In other words, the man provides the form and the woman the matter. This is precisely Aristotle's conclusion, grounded in the same flawed biology, articulated in different language.

However, Philo's second source is scriptural, specifically the first two chapters of Genesis. We see his method at work in his interpretation of Genesis 2: 21-22, when woman is created out of man's rib. Here, Philo seems to both discern and simultaneously validate a theory of sex polarity. He declares that this passage both reveals and confirms the inferiority of woman. This is thus, in Philo's account, a "first principle" derived from Scripture.

Why was woman created from the side of man and not from the earth? Because, says Philo, "woman is not equal in honour with man." ${ }^{36}$ In fact, because woman is made from the side of man, we can say that she takes longer to come into being: "woman is a half of man's body" and "since the moulding of the male is more perfect than, and double, that of the female, it requires only half the time ... whereas the imperfect woman, who is, so to speak, a half-section of man, requires twice as many days ... "37 At least in his account, Philo's more philosophical conclusions are thus confirmed-indeed, revealed - by the Scriptural text. They provided what was taken as a first principle for subsequent interpretations. ${ }^{38}$

There are other references throughout this text that provide additional examples of the gender polarity theory he derives from the Genesis account, but we will have to leave this analysis here. ${ }^{39}$ Like Aristotle, Philo also cannot be held solely responsible for the legacy of sex polarity. However, because of his great influence on subsequent scholars, both philosophers and Scriptural exegetes, his interpretation had an incalculable impact on the understanding of woman's place in the created

33 (Lévy 2018). Sr. Allen tells us that there are two possible explanations for Philo's insistence on a theory of gender polarity: he may have decided to leverage aspects of gender polarity discernible in the accounts of Pythagoras and Plato; or he may have found traces of Aristotle's account in the teachings of the early Stoics, another important influence on his work. See (Allen 1985, pp. 188-90).

34 (Ibid., p. 190).

35 (Philo 1929-1962, pp. 242-42). See also (Allen 1985, pp. 189-93).

6 (Philo 1929-1962, chp. 27, pp. 15-16.)

(Philo 1929-1962, chp. 25, pp. 14-15.)

8 (Allen 1985, pp. 188-93). See also (Sly 1990).

39 (Allen 1985, pp. 188-93). See also (Sly 1990). 
order: She was created second and is therefore secondary in importance and status. ${ }^{40}$ It was this interpretation of Genesis 2 that moved forward in history; combined with other sources, it would come to justify the assumption that the revealed word of God illuminated man's superiority over woman.

These two thinkers, Aristotle and Philo, taken together, shaped subsequent accounts of woman in relation to man. They will merge as important influences in the theories of sexual polarity found in two of the most influential thinkers writing and teaching at the height of the medieval period: The Jewish philosopher, Moses Maimonides, and St. Thomas Aquinas. ${ }^{41}$ The assumptions made by both Aristotle and Philo wound their way into the structures and methods of the academy just as the modern university began to take shape.

\subsection{Sex Polarity Theory and the Modern University}

Interest in pursuing the question of sex identity subsided after Aristotle's death in 322 B.C. as other issues and schools of thought competed with one another for attention. ${ }^{42}$ Both Platonic and Aristotelian ideas concerning the concept of woman were simply adopted and not developed further, due in part to the fact that the later Latin philosophers of the period had no knowledge of the Greek language. They were, thus, left with only second-hand accounts of what the two great philosophers had claimed on the subject, and an ill-defined assumption that there was not much difference between their respective theories anyway. However, in the end, it was Aristotle's concepts and his theory of sex polarity that held sway, a situation that continued until the full force of his arguments took the field at the beginning of the medieval period. Our task now is to illuminate how Aristotle's theory and his methods infiltrated both the content and structure of academic discourse in its more modern form. Again, the extensive account provided by Sr. Prudence Allen will be our guide.

The story begins with the founding of the University of Paris in 1150, one of the earliest universities to be officially chartered by King Philip II of France in 1200. It became the model for all later medieval universities in Europe and marks the beginning of the modern university, shaping both its structure and methods. The turning point came when, in 1255, Aristotle's works became required reading at the University. It was in this way that his philosophy came to dominate and thereafter informed the structure and content of the academy from the 13th to the 15th centuries. ${ }^{43} \mathrm{Sr}$. Allen tells us that, nonetheless, his influence on the formation of both students and faculty had "serious" consequences for the historical development of the concept of woman. ${ }^{44}$

Of course, Aristotle's influence on the academy went well beyond his theories on man-woman relations. For example, his impact on scholarly method would be impossible to overstate. As it also bears on the history of this question, we will consider that briefly now.

Up until this moment in history, the educational enterprise had mirrored the Benedictine monastic approach, which was essentially cooperative and more along the lines of dialogue, when the search for truth often involved reflection on personal religious experience. ${ }^{45}$ Both men and women religious

40 This is not to say that the Gospels, or the writings of St. Paul, or the authors of the other books of the New Testament were influenced by Philo's understanding of woman as secondary and therefore inferior. There is no evidence to support that and it would be incorrect to suggest it. To offer a general interpretation of the passages in the New Testament where women are mentioned would be beyond our purposes here. Much more research needs to be done to offer an interpretation of such passages, especially those found in the letters of St. Paul, in light of the theory under consideration in this paper. Certainly, it is legitimate to speculate, perhaps even assume, that St. Paul would have been aware of the prevailing theory of woman's role in the reproductive act and would have considered it to be valid; that was the science of his times and he would have been familiar with the Greek and early Jewish thinking on this score. However, the hermeneutical key to St. Paul on such questions will be found, not in Greek categories, but in Hebraic anthropology and its understanding of the person as per se communal. We will come to this later in the paper.

41 (Allen 1985, p. 190). See also (Cortest 2017).

42 (Allen 1985, p. 127).

43 (Allen 2002, p. 65). Her chapter on Aristotle's influence on the academy, "Aristotelian Roots of Gender Identity," is worth reading in its entirety. So is all four volumes of The Concept of Woman.

44 (Allen 2002, pp. 65-66).

45 (Allen 2002, chp. 1. See also chp. 2, p. 68). 
participated in this pursuit, sometimes separately, sometimes together. ${ }^{46}$ However, Aristotle's methods and aims were somewhat different. His quest was for scientific and universal truths, detached from personal experience and articulated in a form that corresponded to the rules of rhetoric and the laws of discursive reason, approaches he had already well described in his own writings. ${ }^{47}$ Under Aristotle's tutelage, mediated initially by theologian Peter Lombard (1097-1142), the scholastic method was born. Taken up next by scholars such as St. Albert the Great and St. Thomas Aquinas, the structure of academic discourse took on the form of a debate governed by these methods. ${ }^{48}$ Education now would proceed via the disputation, a procedure in which a Master challenges and likely "defeats" the student through argument and by demonstrating greater command of the topic or question at hand. ${ }^{49}$

These methods, while absolutely legitimate and most certainly fruitful, had to be learned and mastered in order to participate in such discourse. Since, at this point in history, the formal academic community was comprised solely of men, women were not in a position to acquire the necessary mastery, even assuming they would have an opportunity to join in. As we know, it would be many centuries before women would have access to such learning or to membership in the academy. These historical factors would distance women from the scholastic project while at the same time serving to "confirm" the prevailing assumption that such methods corresponded more suitably to men's approach to the pursuit of objective truth. ${ }^{50}$

Unquestionably, the most prominent scholar of the period was the great medieval philosopher-theologian, St. Thomas Aquinas. We will rely on Aquinas' understanding of the person in the next section of the paper. However, a brief comment on his general conclusions on the question of sex identity will help complete the picture and anticipate Aquinas' more general account of the person that provides a way out of this situation. Though his starting place is certainly Aristotle's theory, including the now familiar flawed understanding of human biology and reproduction predominant at the time, Aquinas nonetheless forged a new synthesis that allowed him to arrive at a more nuanced understanding of woman. As such, Aquinas provided the Catholic intellectual tradition with a critically important defense against the wholesale acceptance of Aristotle's theory and preserved the hope of a correction.

At the level of nature, Aquinas' account corresponds almost entirely to the sex polarity advanced by Aristotle. On the natural plane, woman is born imperfect in relation to man. Her being exists as a privation, she remains a passive participant in the act of generation and is also less capable of virtue and wisdom. However, Aquinas does not follow Aristotle's lead in important ways, even as he accepts the Philosopher's basic scientific premise and his conclusions at the level of nature. In the end, his account of woman in relation to man takes a very different shape when he considers this question in light of his theological commitments.

It is an indication both of his intellectual integrity and his firm commitment to his faith that Aquinas did not follow Aristotle's flawed scientific account in every respect. Instead, he affirms woman's capacities and potential at the spiritual level. Perhaps most importantly, his own philosophical anthropology is grounded in Aristotle's account of the person as a unity of body and soul, a "unified existent," equipped with all the powers of reason and will. This is the basis of Aquinas' broader theory of man in the universal sense. It will allow us to extend his categories and articulate a more comprehensive account of the nature of woman in relation to man in the next section of the paper. We will come to that shortly.

46 (Allen 2002, p. 67).

47 Several works of Aristotle's contain his account of these methods. See (Aristotle 1941).

48 Lombard was referred to as "Doctor Scholasticus" and is responsible for the development of what came to be known as the scholastic method. (Allen 1985, p. 272).

49 (Allen 2002, p. 68).

50 (Ibid., pp. 66-67). 
Aquinas is operating within a horizon of grace, permitting him to maintain and leverage a fundamental premise of Catholic theology, that "grace perfects nature." ${ }^{51}$ This gives him free reign to argue that, though woman starts life as a "lesser" creature, in the end, she may arrive at a full relation of sex complementarity with man. She has the capacity to develop, and, under the influence of grace, she can achieve full equality with man and be equally capable of infused wisdom and the theological virtues of faith, hope, and love. In his account, man is not superior to woman in the realm of the divine; in heaven, man and woman are equal.

A more detailed analysis of this historical period is beyond our purposes here. Suffice it to say that it was inevitable that Aristotle's sex polarity theory, confirmed by Philo's Scriptural interpretation, would infiltrate any further discussion of the concept of woman. Sr. Allen tells us that, had Aristotle's impact been more isolated and limited to the thought of just a few of the thinkers that populated the medieval period, things might not have developed as they did. However, as history shows, Aristotelian arguments became a permanent feature of the infrastructure of the western educational system. His theory of the concept of man and woman achieved "a decisive victory over the direction of human thought." 52

This victory was achieved first through the spread of the university system when Aristotle's works became required reading across all of Europe. However, the pervasive presence of numerous mendicant orders further insured and accelerated the spread of his thought. These traveling preachers were themselves well-trained and were able to translate otherwise complex arguments into the language of the "man on the street." Through their efforts to preach far and wide in order to educate the ordinary citizens of the countries in which they travelled, Aristotle's thought began to infiltrate the minds of the population and western culture at large. In this way, his theory of sex polarity was widely disseminated, discussed, and written about as various authors, both scholarly and otherwise, took up the task of developing the theory further. The Aristotelian Revolution, says Sr. Allen, "achieved a definitive victory for the Christian west, which was to remain in effect, in some respects, even up until the present." 53

When Aristotle's heliocentric theory of the cosmos was challenged and thrown out by subsequent scientific discoveries, his metaphysics and anthropology went with it, and his direct influence on the concept of woman — or at least explicit reference to it—faded away. However, by then it was too late to change the trajectory of thought on what had become a pervasive theory of woman. By the 16th century, assumptions concerning the superiority of men over women were well-established in the familial, social, and political structures of the culture. Subsequent developments in theology and philosophy would do nothing to alter the course. ${ }^{54}$ With some exceptions, philosophers would spend the next several centuries trying to articulate the basis either of a sex polarity theory or some form of the sex unity theory. Descartes would merely neutralize the question. He rejected the hylomorphic structure of real things in the world, then posited two distinct substances, separating the body from the soul in his account of the person. ${ }^{55}$ Descartes' person was mostly a res cogitans, a "thinking thing" barely attached to a body; no significant distinctions between men and women were possible in such a vision. After Descartes and the Cartesian revolution, only Immanuel Kant and Jacques Rousseau

51 Since St. Augustine's treatise On Nature and Grace in the fourth century, Catholic teaching has held to the doctrine that grace is not opposed to nature but is that which liberates and controls nature.

52 (Allen 1985, p. 413).

53 (Allen 1985, p. 411). This is true to the extent that Aristotle's gender theory influenced Christian thinking on woman. However, this is not to imply that the authors of the New Testament were necessarily influenced by Aristotle's theory. Sr. Allen is speaking more on a sociological or cultural level. She is not making a claim about the meaning of Scripture.

54 Including Martin Luther's Reformation in the mid-16th century, and the entire modern period, from Descartes (d. 1650) to Kant (d. 1804). See (Allen 2002) Part One and Part Two, and (Allen 2016).

55 (Allen 2016, p. 248). 
offered anything of substance on the question. Their accounts are very similar-and both devalue women..$^{56}$

In truth, the historical facts reveal that, in a sense, these errors took on a life of their own. From the medieval period, through the so-called Enlightenment period, and up until the 20th century, they served as the point of departure, sometimes explicitly, but usually not, for philosophers and theologians (and ordinary men and women) as they attempted to offer new grounds for explaining man's superiority over woman. The impact of these premises accelerated in the late 19th century when they were appropriated, distorted further, and weaponized by Frederic Engels; Engels' conclusions were subsequently tragically incorporated into the advance of Marxist thought. ${ }^{57}$ Finally, they found their way into the existential atheism of Jean Paul Sartre and his mistress, Simone de Beauvoir, whose own work served as the spark that launched the second wave of feminism in the mid-20th century. ${ }^{58}$ It should surprise no one that when women finally began to find a path into the professional academic disciplines, they turned to sources other than Aristotle or Aquinas when searching for a way to articulate their concerns. However, unfortunately, the sources they relied on, both then and since, have not led them to any real satisfactory solution. Instead there is a widespread rejection of the existence of a human nature and a new conviction that sex and gender are merely social constructs that we create ourselves. Our sexual identity is now a performance, not an actual feature of who we are. ${ }^{59}$ The women's movement is in a sort of holding pattern as society tries to sort out what it means to claim that one even is a woman. Amidst competing accusations of toxic masculinity and femininity, the breakdown of the family evident in widespread divorce and fatherless homes, and the prevalence of violence and loneliness, our culture is simply confused, with no clear way out of the morass. ${ }^{60}$ We are witnessing a rupture between the men and women of our time, fueled by ideology from all sides, questionable social science, burdened further by anonymous sexual encounters. Ironically, the place that women occupy in the scheme of things remains a disputed question.

It would appear that the truth of Aristotle's caution, stated at the start of this essay, that "the least initial deviation from the truth is multiplied later a thousand-fold" has been demonstrated in full. It is time to acknowledge the ancient starting place of our confusion-and to offer a correction.

56 Ibid., p. 340. It would not be until John Stuart Mill's famous essay The Subjection of Women published in 1869, that anyone spoke out formally and publicly against the generally accepted idea that woman should be subject to the dictates of her husband or father since, according to the social norms of the time, it was understood that women were both physically and mentally less able than men, and therefore needed to be "taken care of." See (Mill 1997). In England, it was not until 1870 that married women were allowed to own property. See (Combs 2005, pp. 1028-57). In the U.S., it was not until the passage of the 19th amendment in 1920 that women had the right to vote.

57 (Engels 1884), Chapter Two, (the Family), Section Four, (The Monogamous Family). It is public domain now and is cited online at https://www.marxists.org/archive/marx/works/1884/origin-family/ch02d.ht.

58 The suffragist movement is considered the first wave of feminism. The second wave of feminism is said to have begun with Betty Friedan's The Feminine Mystique, written in 1963. Friedan's account differs from that of the French philosopher Simone de Beauvoir, author of The Second Sex. However, Friedan dedicated her own book to de Beauvoir and considered herself to be in debt to Simone as her political and historical predecessor. de Beauvoir's existentialist argument that "woman is not born, she is made" provides the hidden philosophical underpinnings of current "gender" theory and its convictions that the existence of human nature is a myth and that "gender" is merely a social construct (Friedan 1963).

59 Illustrative of this thought is the work of Judith Butler. See, for example, her well-known book (Butler 1990) or (Butler 1993).

60 See in particular the 2018 report from the American Psychological Association on Boys and Men. Intended to establish new guidelines for psychologists when working with boys and men in therapeutic encounters, it stipulated that "traditional masculinity" was, by definition, "toxic." These guidelines were recognized immediately as an "ideology being substituted for a clinical diagnosis." See (Siglioto 2019), https://www.thepublicdiscourse.com/2019/01/48967/. The authors of the report were forced to retract or soften many of their claims within days of its publication though their assumptions live on in the culture. Here is a link to the revised report: https://www.apa.org/about/policy/boys-men-practice-guidelines.pdf. Perhaps predictably, these developments have led to additional claims about the existence of "toxic femininity" as well. Though accounts of this phenomenon are less substantive and varied, psychologists seem to be drawing similar conclusions. Toxic femininity appears when women display stereotypical, "traditional" feminine behaviors such as "passivity, empathy, sensuality, patience, tenderness, and receptivity," behaviors also assumed to be the result of social conditioning alone. See https://www.psychologytoday.com/us/blog/sex-sexuality-and-romance/201908/toxic-femininity. 


\section{The Solution: Revisiting Genesis 1 and 2}

We will now turn our attention to correcting this historical error, at least from the point of view of the hermeneutic suggested by one inarguably prominent philosopher-theologian in the Catholic tradition, Pope St. John Paul II. Genesis 1 and 2 will now be reinterpreted through a philosophical lens-not of a sex identity theory - but through the lens of Aquinas' metaphysical account of the human person, itself refracted through a more properly Hebraic anthropology. Our hypothesis is that, taken together, the two creation accounts reveal a vision of man and woman as equally and fully human, equally endowed with intellect, will, and freedom, with two distinct and complementary ways of operating in the world. ${ }^{61}$

In the opening pages of The Theology of the Body, Pope St. John Paul II declared that we can derive an account of the human person from the two distinct creation accounts found in Genesis 1 and 2 . He argued that the first creation account reveals the meaning of man in the abstract, man qua man, that is, as an objective reality, created in the image of God. The second account reveals this meaning in the aspect of his subjectivity. ${ }^{62}$ He states that the "powerful metaphysical content" hidden in Genesis 1 has provided "an incontrovertible point of reference and a solid basis" for metaphysics, anthropology, and ethics and been a source of reflection throughout the ages for those "who have sought to understand 'being' and 'existing.'"63 However, in Genesis 2, he goes on to say, the depth to be uncovered in this second (though historically earlier) creation account has a different character; it "is above all subjective in nature and thus in some way psychological." Here we find man in the concrete, as a subject of self-understanding and consciousness; here the account of the creation of man refers to him "especially in the aspect of his subjectivity." ${ }^{\prime \prime} 4$

John Paul II himself did not fully exploit this claim, stating that his intent is not to pursue this more metaphysical account of the soul in union with the body, but to focus instead on the "meaning of one's own body." ${ }^{65}$ It is nonetheless an intriguing argument begging for further investigation. And so, in what follows, we will consider John Paul's claim by providing a more complete analysis of these texts through the lens provided by two distinct accounts of the person: first, an explicitly biblical anthropology and second, the metaphysical anthropology of St. Thomas Aquinas. The first will allow for a direct reading of the text in its original language; the second will help us to determine whether John Paul's use of more properly philosophical categories as an interpretive device is justified. Our thesis is that both of these approaches, taken together, will allow for a more precise account of the nature of man and of woman as ontologically equally human subjects, who are, at the same time, differentiated in relation to one another.

As we begin, let us recall Sr. Allen's caution, that every theory that claims to explain the identities of man and woman must account for two anthropological principles: The principle of equal dignity

61 The following analysis is based in part on previous research published in (Savage 2014). Significant refinements to the theory have been made since then. The version offered here represents a major refinement of the theory since it now reflects the insights from Hebraic anthropology, not included in earlier iterations.

62 (John 2006, pp. 136-37).

63 (John 2006, pp. 136-37).

64 (John 2006, pp. 138-39). These two categories, "being and existence" and "personal subjectivity," are foundational to the thought of Karol Wojtyla/John Paul II. Throughout his writings, this philosopher pope frequently contrasts the philosophy of being (metaphysics) and the philosophy of consciousness (phenomenology) and seeks ways to reconcile and synthesize their claims. His own anthropology is a creative completion of the Aristotelian-Thomistic account of man in which he synthesizes the metaphysical anthropology of the Thomist tradition with a more phenomenological analysis of human experience. He is concerned to correct what he perceives to be an inadequacy in the received tradition on the meaning of the person. The tradition has relied on the Boethian definition of the person as an "individual substance of a rational nature" which, he argues, though it provides the necessary "metaphysical terrain" in the dimension of being and paves the way for the realization of personal human subjectivity, leaves out an adequate investigation of lived human experience and thus lacks an essential component of what it means to be an actual living person. The thrust of his effort is to capture the meaning of human personhood in light of both the objective nature of the person and his lived experience as the subject of his own acts. See "Subjectivity and the Irreducible in the Human Being," (Wojtyla 1993, pp. 209-17).

65 (John 2006, 7: 1-2). 
and that of significant differentiation. ${ }^{66}$ Both of these conditions must be met for both man and woman to find their place in any truly human civilization. We will seek to conform to these criteria here.

\subsection{The Principle of Equal Dignity: Genesis 1}

Our analysis will focus first on one particular pericope found at Genesis 1: 26-27. Here are the specific passages of interest: At Gen 1:26, God says "let us make man (adam) in our image. At Gen 1: 27 we read: "So God created man (ha'adam) in his own image, in the image of God he created him (otho); male and female (zâchâr and nikevah) he created them (otham)." ${ }^{67}$

The starting place for the hypothesis is the use of the terms adam in the first passage and ha'adam in the second. These will provide us with our point of departure and allow us to claim that the first creation account reveals that man and woman are both instantiations of the same human nature, with all that this implies. The argument begins with a consideration of the meaning of the word adam, traditionally translated as "man." It is the full meaning of this term that requires investigation. Here, we need to consider two principles central to Hebraic anthropology: The meaning of "corporate personality" and its relationship to the theory of the soul.

It can be difficult for those invested in modern notions of the person as an autonomous, self-determining individual to grasp how profoundly different is the point of departure for the Hebraic account of the person. Its starting place is the principle of the "corporate personality." 68 It is this concept that provides the first hermeneutical key to interpreting the biblical texts under investigation. It will allow us to unpack the intended meaning of adam and ha'adam.

In the Semitic account of the person, itself derived from scripture, the individual is never, even in his or her concrete existence, an atomistic self, isolated from the community in which he or she is imbedded. ${ }^{69}$ The individual person is an instantiation of the "organic unity" constituted by an ontologically prior corporate reality, not in a metaphorical or symbolic sense, but in terms of what one scholar refers to as a "single group consciousness." ${ }^{70}$ This is the principle of corporate personality; it is a reference to the idea that the "one" represents the "many" and the many are contained in the one. ${ }^{71}$ That is, the individual stands as both the one and the many. The community is literally embodied in the individual whose own existence renders present (in real time and space) both past and future generations. ${ }^{72}$

Importantly, in this account, the individual is neither absorbed into the community nor ontologically cut off from it. He does not suffer a loss of personal identity; his identity is intimately and organically connected to the community. He is indeed an expression of the "corporate personality." The Semitic worldview thus held the "personal and corporate aspects of the person in a dynamic, positive tension." ${ }^{\prime 73}$ It is a form of "biblical personalism which proclaims the integrity of the individual

66 (Allen 1985, 2016. )

67 The author is indebted to several scholars in translating and interpreting these passages. First, Monsignor Michael Magee, chair of the Systematic Theology Department and professor of Sacred Scripture at St. Charles Borromeo Seminary in Philadelphia, who helped with the meaning of the original Hebrew texts and was the first to affirm the merits of the hypothesis. Dr. Joseph C. Atkinson, Associate Professor of Scripture at the John Paul II Institute in Washington, D.C., has provided enormous assistance in arriving at this interpretation. Dr. Michael Waldstein, editor of the definitive text of John Paul II's Theology of the Body and Professor of Theology at the University of Steubenville, has been extremely helpful in assisting in the refinement of that interpretation.

68 Dr. Atkinson argues that the idea of the "corporate personality" is the most promising principle for grasping the anthropology at work in the Old Testament. See (Atkinson 2014, p. 163). I am immeasurably indebted to Dr. Atkinson for both his work and his guidance in this area. For a thorough treatment of the meaning of the Hebraic principle of corporate personality and a comprehensive review of the literature on the topic, see Chapter 6, pp. 161-92. The definitive text on this topic is a manuscript by (Robinson 1967).

69 Dr. Atkinson offers an analysis of the evidence from Scripture in Chapter 6. (Atkinson 2014, pp. 170-73).

70 (Atkinson 2014, p. 164). Here quoting Robinson.

71 (Atkinson 2014, p. 165).

72 (Atkinson 2014, p. 165)

73 (Atkinson 2014, p. 168). 
person in relation to the group, while at the same time admitting that the individual person can ... represent the entire group." 74

This vision of the person as a reflection of a corporate personality is grounded in the Hebrew account of the soul (nepesh). In this view, the soul is not "infused" into the body of an individual in the sense that two "parts" come together to form one whole, as more modern formulations of the soul in relation to the body tend toward. Instead, the person, in his total essence, is his soul, which is itself organically linked to the ontological reality of the entire community, past, present, and future. It is the Hebraic account of the soul that allows for the tradition's further claim that the individual person always exists as part of a much larger reality, which is constitutive of his existence and of which he is the concrete expression..$^{75}$ Here we see clearly that, in biblical anthropology, the "oscillation" between the one and the many takes place at the level of the concretely existing person, instantiated as he is by a human soul that is itself organically united to the whole community.

This admittedly brief excursus into Hebraic anthropology prepares us to return to our text and consider the meaning of adam and ha'adam in light of these two principles. We will take up the term adam first. ${ }^{76}$ We find it at Gen 1:26 when God says, "let us make man (adam) in our image." We now know that the translation of adam as "man" does not adequately capture the actual meaning of the term. Indeed, as we will see in a moment, the only thing that comes close to its meaning in English translation is the signifier "man as such" or the familiar "man per se." The Hebrew author of Genesis 1 is referring here to adam (itself taken from adama or earth) as an instantiation of the "corporate personality" referenced above. The creation of adam signifies the creation of the whole human race rather than merely an individual. However, while adam contains all members of the community, it also retains connotations of personhood and concreteness. Here we see the significance of the "oscillation" between the one and the many so essential to biblical personalism. However, unlike the signifier "man per se," it is not an abstraction; the Hebraic reference is always to a concrete existent and therefore includes a bodily existence. Also, since this moment in the text is a reference to the creation of the first human being (and again, not the abstraction "man per se), it must be interpreted to mean that the first human being was male. However, as we have seen, simultaneously contained within that existent, indeed, already present within adam, is the first woman. Additionally, while the connotation of adam extends to all of humanity, this reality can only take on a concrete existence through the creation of the first woman, something made clear in the very next passage. ${ }^{77}$

At Gen 1: 27 we read: "So God created man (ha'adam) in his own image, in the image of God he created him (otho); male and female (zâchâr and nikevah) he created them (otham)." ${ }^{78}$

The meaning of $h a^{\prime}$ adam is easily stated: $h a^{\prime}$ is a definite article and the reference now is to the man. The text has introduced a new level of specificity to the creation of adam but has now declared adam's existence as embodied in manifestly masculine and feminine form. Thus, the priceless dignity

74 (Ibid., pp. 166-67). Dr. Atkinson is citing Jean (de Fraine 1965, pp. 14-15). The original quote is from A.M. Dubarle in Melange Lebreton, RSR 39 (1951/53), I, 59.

75 (Atkinson 2014, pp. 173-75). See also, (Pedersen 1959, I-II, 99).

76 It is important to note that, though we have always thought of the main characters in these first two chapters of Genesis as Adam and Eve, only Eve is ever actually named - and even then, not until after the fall. The reference here is most certainly NOT to "Adam," the husband of Eve.

77 Though "'adam" can be used to designate the individual man so called, and also another individual man, what is meant in a particular passage would be clear either from the context or from the use of the definite article with it: viz., if the reference is to hâ'adam, it would refer back to some man already indicated from the context. In Gen 1:27, the "man" already indicated from the context is precisely the individual man who also stands for the collective: The word " adam" mentioned in v. 26 is without the definite article and therefore can be said to indicate man as such. Thus, 'adam is a reference to man per se, not to an individual or particular human being. A different word-either hâ'adam or 'îsh —would have been used (both these terms are used in both the first and second creation accounts) if the intention was to refer to the individual man or that particular man the tradition has come to refer to as Adam, the husband of Eve. So, it is really not going too far to say that if there were a reference to the notion of man qua man in Hebrew it would be 'adam.

78 Otho is a contraction of the untranslatable object marker (oth) and the masculine pronoun (o). Otham is the object marker contracted with the masculine plural pronoun (am). The grammatical gender is masculine, which is the "default" gender for a mixed group of males and females. 
afforded the first adam, created in the image and likeness of God, is extended to zachar and nikevah. It is zachar and nikevah who are instructed then to "be fruitful and multiply, fill the earth and subdue it" at Gen 1: 28. Here we can anticipate the differentiation that will become more explicit in the second creation account (Genesis 2: 22); Genesis 1 reveals that it issues out of a unity that already existed in the original "one". ${ }^{79}$ So, though there is an order to creation that places man in the position of primacy, this in no way compromises the dignity or ontological status of woman. This order will repeat itself in Genesis 2 where it will become even more clear that woman possesses a value that mirrors that of man.

We are now prepared to consider John Paul's claim that the first creation account is a reference to man in the "objective" sense, that is, man qua man, or man in the abstract. Does the text support such an interpretation?

The metaphysical anthropology of Aristotle, subsequently leveraged and further developed by St. Thomas Aquinas, though grounded in experience and observation of the human person, his powers, and his acts, employs the method of abstraction; that is, it prescinds from the individuating conditions of matter to arrive at more general, universal principles. All existing things are reflections of two principles, form and matter (if inanimate), soul and body (if living). Man, as such, though an abstraction, is understood to be a union of these two principles, a union of both body and soul, possessing a rational nature, intellect, will, and freedom. This is "man" in the universal sense and every individual instantiation of a rational soul, both male and female, is an expression of this universal human nature.

We have seen that ancient Semitic thought did not have the concept of a universal human nature or the notion of a "substantial form," that which makes something what it is essentially. These were terms introduced by the Greeks. However, given what we now know about the meaning of adam as an expression of a "corporate personality" containing all of humanity, we can argue that it is perfectly legitimate to say that if there were a reference to the notion of man qua man in Hebrew it would be 'adam. In this context, adam is clearly a reference to man in the universal sense. So, when God says, "let us make adam in our image," we can safely say that the reference is an approximate equivalent of our concept of man per se. That is, it can serve as an approximation of or reference to the creation of the instantiation of the "substantial form" that constitutes the human creature. ${ }^{80}$

The significance of this conclusion in light of contemporary concerns for the "equality" of men and women would be hard to overstate. It provides the first explicit element in the solution to the problem under investigation here. It shows definitively, now in philosophical terms, that Scripture itself reveals man and woman to be equally human. Man and woman, here at the level of the species, are both instantiations of the same substantial form and are therefore equally endowed with intellect, will, and freedom. All men and women who, together, comprise the human species, are equally human in every respect. They are both ontologically absolute subjects, possessing individuality, human agency, and the powers and potencies definitive of the rational soul.

This analysis has shown that John Paul II is justified in arguing that Genesis 1: 26-27 is concerned with the creation of man in the objective sense, a formulation that, though it corresponds to the categories employed in the metaphysical anthropology of the Aristotelian-Thomistic tradition, finds a correspondence in the Hebraic account of the person. Both approaches demonstrate from Scripture that man and woman are equally human reflections of the principle of equal dignity. However, this

79 (Atkinson 2014, Biblical and Theological Foundations, p. 171). Dr. Atkinson is here referring specifically to Genesis 2 but, given (as we will see) that similar terms are used, this can also be applied to Genesis 1.

80 The word 'îsh, on the other hand, designates specifically the male, the concrete individual man, because the word zâchâr is the one used in an adjectival sense for "male" (it is related to the word for "remember," perhaps because of the computation of genealogy through the male line). Sometimes 'îsh is also used in the sense of "each one, each man." The word 'îsh is not used at all until Gn 2: 23, right after the woman is created and Adam is naming her ishshâh — while saying this is because she is taken from the 'îsh. To avoid any illegitimate leaps in interpretation, the best way to maximize care and precision would be to say that, of all the terms available in Hebrew, the one that would have to be adopted to designate what later philosophy would refer to as man in the abstract would have to be 'adam. It is this word that stands for "man" as the English language has traditionally and collectively used the word; it corresponds to the Greek anthrôpos, the Latin homo, the German mensch, or the Polish człowiek. 
is not to say that they are interchangeable. We still need to consider that which differentiates them, a topic taken up in the next section of the paper. However, it is important to make explicit the fact that these conclusions can be and have been drawn directly from the exegetical tradition that has itself, in many ways, maintained the theory that man is superior to woman. The above analysis has called that conclusion into question by leveraging the same categories used throughout history to arrive at it. The same method will be used in what follows.

\subsection{The Principle of Significant Differentiation (Part One): Genesis 2}

The first account has established that man and woman are equal in dignity. In the second account, we begin to see what differentiates them. It is here that, according to John Paul II, God creates man and woman in their personal subjectivity. At Genesis 2: 7, man (referred to here as hấadam, or the man) is fashioned from adama, from the earth; he is the first human being; we know now that he is a reflection of both the one and the many. Gradually he realizes that he is alone, and so, in a separate, creative act at Genesis 2: 22, woman is made or built (banah) out of one of the man's ribs (tsela). Here God brings forth woman from the already existing ha'adam, who is himself made in the divine image. Thus, both become the bearers of that image, both possess absolute value and dignity. The man declares "here at last is bone of my bone, flesh of my flesh." He recognizes woman as a person like himself. Indeed, she is his mirror image and, with her appearance, ha'adam awakens to his own subjective existence. Both God and the man are finally content that a proper helper (ezer) has been found. ${ }^{81}$ However, what must get our attention immediately is the fact that it is not until this moment in the text (Genesis 2: 22) that the sacred author refers to man and woman for the first time as concrete subjects of existence, as real existing persons. They are only now 'îsh and: Man and woman as actual. As John Paul II points out, there is no 'îsh without ishshâh, for it is not until ishshâh appears that the man, previously referred to ha'adam, is finally referred to as 'îsh. Though man maintains the place of primacy (ishshâh is made from 'ish), the plain meaning of the text is clear: There is no concretely existing man without a concretely existing woman; they appear in the text together, at least in terms of their specific identity. It is ultimately these two persons who will be referred to as Adam and Eve. ${ }^{82}$

In philosophical terms, when viewed through the lens of Aquinas' anthropology, this second account of creation can be seen as a description of the moment when signate matter and the principle of individuation have entered the picture. Man and woman (the 'îsh and the ishshâh) of the second creation account are the result of particular matter (earth; rib) being introduced; the substantial form or soul that makes man what he is absolutely (adam) illuminated in the first account has now found individuation and differentiation via the designated (common) matter that the form animates in the

81 (Atkinson 2014, Biblical and Theological Foundations, p. 170).

82 This is a somewhat different interpretation of this passage from that of other scholars, in particular that of (John 2006). There he argues that the reference to man at 2: 7 is a reference to man in the abstract or collective sense. However, my reading of the text and its use of ha-adam to refer to "man" in that passage leads to the conclusion that it is a reference to a specific "human being," in this case a man. As stated previously, in the Hebrew, adam without the definitive article ha, can refer to man in the collective sense (see Gen 1: 26). However, when the definitive article is used, it is a reference to a specific "human being," and, in this case, according to the narrative that follows, one who is male. Indeed, the narrative goes on to reveal that it is from the man's (ha'adam) rib that the woman (ishshah) is created. It seems clear from the passage that the reference is to the man, that is, the concrete person of the ha-adam, while a specific individual, is at the same time representative and as it were 'contains' the whole of humanity, an interpretation that is very much in accord with Semitic thinking. However, it is essential to affirm as well that John Paul II is absolutely correct to point out that it is only with the creation of isshah (the concretely existing woman we have come to refer to as Eve) that 'ish (the concretely existing man we have come to refer to as Adam) appears. There is no 'îsh without isshah. Some scripture scholars want to argue that Genesis 2 must be interpreted in light of Genesis 1's reference to adam and that woman and man are created simultaneously from adam in both accounts. Along with Brevard Childs, I dispute this interpretation. The Hebrew text is clear and direct in this instance. Gen 2:22-23 states that the matter from which the woman (ishshah) is formed is from the ha-adam and that the woman (ishshah) was taken out of the 'ish. See (Childs 1985, pp. 189-194). A careful reading of both the text and the narrative reveals the clear meaning of Genesis 2. The author is indebted to her colleague, Dr. Mary Lemmons, for suggesting that this point be clarified and to both Monsignor Michael Magee and Dr. Joseph Atkinson for their expertise in helping to confirm this interpretation. 
second. The complementarity that characterizes the nature as such has now been embodied in two concretely existing beings, differentiated by two distinct but related kinds of matter. ${ }^{83}$

However, the difference between man and woman is not reducible to merely the material element. Though a comprehensive treatment would take us too far from our purpose, this requires further explanation. From our analysis so far, we can conclude that both man and woman are equally human since both are an embodiment of a substantial form common to the species humanum. However, both must be seen to be distinct instantiations of the species, made as they are of different signate matter. They are animated by souls that are "commensurated" or adapted to their individual person. ${ }^{84}$ It is the meaning of "commensuration" that lends the clarity we need.

This "commensuration" reflects both the universal structure of male and female and the personal structure of any one particular man or woman: Man per se is a composite of body and soul, each man or woman is a composite of this body and this soul. However, gender is not reducible to matter; it has an ontological component since gender is the type of accident that is attributed to the subject qua subject, that is, to the whole composite of soul and body that constitutes the subject as a unity. ${ }^{85}$ So, here offering woman as our example, though matter is one of the things that differentiates woman from man, since woman is composed of both body and soul and since the soul of each individual woman is meant for her (that would be commensuration), she is in some essential way, a woman. That is, gender is an accident not merely of the matter, like the color of her hair or her eyes. Her woman-ness does not reside in her merely in the matter of which she is made. It is who she is, as John Paul II states, both physically and ontologically. These same things can be said of man: He is in some essential way, a man. Men and women are equal, composite creatures and, at the level of the individual person, differentiated by both the matter of which they are made and the soul that animates them. This is true of both of them. And here we can say that John Paul II's claim that Genesis 2 describes man "in his subjectivity" is justified.

Let us pause here to highlight this important point: This account of the equality and difference that characterizes man and woman reveals that neither the male nor the female of the species is normative for the species. How so? Because at the level of man or woman per se, we are differentiated in exactly the same way. Both woman and man are equally human; the sexual difference that characterizes man and woman is rooted in a particular kind of philosophical "accident" driven by but not reducible to the matter of which they are made. Men and women are both composite creatures, a union of body and soul, whose gender is an inseparable accident (but an accident nonetheless) attributable to the composite itself. They are the same in terms of that which differentiates them from each other.

The implications could not be more significant, for here we have a philosophical demonstration, grounded in Scripture, that women do not have to act like men to be considered human any more than men have to act like women to be considered human. There is absolutely no risk to the "equality" of men and women in understanding their nature in this way. Man and woman are equally human but

83 Again, the philosophical principle at work here is that what is found in the effect must first be in the cause.

84 In the creation account found in Genesis 2, we are no longer speaking of man in the abstract (adam) but individual persons. The Hebrew text includes reference to both ha-adam ("the human being" which, in Genesis 2, is a reference to a male at the level of the species, and ish and isshah, which refer to a concretely existing man and woman). At this point, matter (dust, man's rib) enters the picture. Also, as Aquinas states, we thus enter the realm of accident. Aquinas explains gender as a type of (inseparable) accident. See (Aquinas 1968, 6, 5, p. 68). However, since this type of accident is said to be something attributable to the species, the categories of male and female, while certainly inseparable from the essence of the person, cannot be attributed to the species per se. To be "male" and "female" is a special kind of inseparable accident, perhaps even in a category all its own. See (Finley 2015, pp. 585-614).

85 (Aquinas 2014, II, 81, 8). The author is indebted to Sister Prudence Allen and Monsignor John Wippel for pointing out this passage. Though it does not deal directly with the distinction between genders but with the individuation of the human soul and its continuing individuation after it is separated from the body at death. It is here that Aquinas introduces the notion of the commensuration of each soul to each body. Commensuration is a term that means literally to have the same measure. Aquinas means here that each body is adapted or accommodated, even interpenetrated in an equal measure by the soul intended for it. See also (Aquinas 1952, Q 5, 10) where Aquinas states: "the soul when joined to a body imitates the composition of that body." 
different, a fact immediately discernible in human experience and accessible to scientific analysis. ${ }^{86}$ Thus, sex polarity of any sort is put to rest; the historical error is corrected. Woman is redeemed, freed, at least in theory, from Aristotle's claim that woman is a "malformed" male. However, there remains the need to account for Philo's contribution to this state of affairs. We need to reconsider the significance of the creation of woman at Genesis 2: 18-34. Here it will be shown that, when considered together, Genesis 1 and 2 illuminate more fully the meaning of the second creation account and its significance for our understanding of the creation of man and woman. In particular, such a reading will dispute Philo's claim that woman is created second because she is "less honorable" than man. In fact, it will dispute the claim that woman is created "second" at all.

\subsection{The Principle of Significant Difference (Part Two): Genesis 1 and 2}

This somewhat foreshortened analysis of Genesis 1 and 2 does establish both the equality of men and women and their difference. However, there is more to be found in these texts. Considered together, they allow us to illuminate more fully the meaning of the second creation account and its significance for our questions here.

Let us return first to the creation account found in Genesis 1. Here, the author lays out a particular hierarchical order in which God clearly creates. God begins with the heavens and the earth, and then gradually makes his way up the scale of creation to the moment where it all culminates in the creation of adam, embodied in ha'adam and containing both the first man and the first woman. This is clearly a hierarchy that is on its way up, from lower life forms to higher.

Pausing again over what we discover from the second account, we read at 2: 7 that hâadam is made from the dust of the earth. When, at Genesis 2: 18, God sees that the man is alone, God forms every creature and brings them to the man to be named. Then God, realizing that none of the creatures correspond to the man's own being, and that it is not good for him to be alone, decides it is necessary to make a fitting helper (the full text is 'ezer kenegdo) for him ${ }^{87}$ - then puts him into a deep sleep and forms the woman ('issah) from man's ('îsh) rib (tsela). ${ }^{88}$ Upon awakening, Adam says, "This at last is bone of my bones and flesh of my flesh" (Gen 2: 23-24). As John Paul II points out, man recognizes in woman another person, a being equal to himself, a someone, not a something-a someone he can love, to whom he can make of himself a gift, and who can reciprocate in kind. This seems fairly straightforward.

However, there are several additional and important points to glean from considering these two chapters together. First, it is only when we come to the making of Eve that we see the final significance of the order introduced in the first account and brought to completion in the second. ${ }^{89}$ Adam is made from the earth (adama) but Eve is made from Adam. Though it has troubled feminists forever-and is

86 Though it will not be possible to include it here, it should also be noted at the outset that scientific research regarding what distinguishes men and women supports many of the conclusions found in the work of John Paul II as well as in this paper. See (Rhoades 2004, pp. 22-26); (Jessel and Moir 1991, pp. 68-112). For additional sources and a critique of brain organization theory as a whole, see (Rebecca Jordan-Young 2010). The author's general argument is that there are risks associated with attributing sex differences to hormones and that brain organization theory (found in these other sources) cannot account for all of them.

87 The word ezer is translated in many different ways: A "suitable helper," "suitable partner." Perhaps the best is found in the Jewish Tanakh—a "fitting helper."

88 Though the word tsela is traditionally translated as "rib," it is not at all clear that this is correct. The basic meaning of the word in Hebrew is ambiguous and there are quite a few possibilities, including "plank," "side," and references to geographical and architectural terms. There have been many hypotheses concerning the word but the only thing that is really clear is that, if it does mean "rib," it does so only in this one passage. Several possible interpretations have particular appeal: If it is taken to mean "side" or "plank," it could be thought to be the source of the expression that woman is man's "better half"; or, given its proximity to the heart, it has been taken to stand for human interiority. Perhaps the most satisfying possibility is that it is a reference to sacral architecture since in some contexts tsela refers to the side portions of the sanctuary that are necessary for its stability and function. The conclusion can be drawn that the Yawhist author of the passage used terminology "designed to evoke associations with the construction of the sanctuary" to suggest that human beings "come to fulfillment for which they are destined by creation only as man and wife and as God's temple." See (Botterweck et al. 2003).

89 This interpretation is supported by Brevard Childs who states that "the creation of the woman, which is sequential in time, foreshadows a climax to the creation which resounds with joy at the close of the chapter." See (Childs 1985, p. 191). 
arguably the root of Philo's historical misinterpretation of this passage-the fact that Eve is created second is not to make her subservient. For in the hierarchy thus established, woman is not created "second"; she is created last. She is, in fact, made on the way up — the last creature to appear, a creature made, not from earth, but from something that arguably already contains a greater actualization than dust or clay. ${ }^{90}$ It does seem as though she is made of "finer stuff." In any case, because of the order suggested by reading the accounts together, Eve can be seen as the pinnacle of creation, not as a creature whose place in that order is subservient or somehow less in stature than that of Adam. For it is only at the moment of her creation that man realizes who he is. It is her appearance that reveals to man the nature of his own personhood.

This proposition is reinforced when we consider that the Hebrew word usually translated as "helper" is "ezer" which does not mean servant or slave. ${ }^{91}$ When this word is used elsewhere in Scripture, it has the connotation of Divine aid. ${ }^{92}$ Used here to express helper or partner, it indicates someone who is most definitely not a slave or even remotely subservient-there is the sense of an equal, a partner, help sent by God. ${ }^{93}$ Thus, Eve is not to be his servant-a different word would have been used if that were the intention-but someone who can help him to live.

However, an additional, equally significant insight appears when we consider the full meaning of this moment in the text. Woman is described as ezer kenegdo; kenegdo is a preposition that means "in front of," "in the sight of," "before" (in the spatial sense). Thus, we can conclude from the text that woman is not "below" man in the order of creation, nor is she above him. She stands in front of him, before him, meeting his gaze as it were and sharing in the responsibility for the preservation of all that precedes them. Woman and man are complementary creatures; both constitute the "other" for each other. So, another misunderstood element in the tradition-that woman is subservient to man, sent to be merely his servant-is corrected. Woman's significance is revealed in its full meaning. Woman's place in the order of creation reveals her true nature and mission — that of help sent by God to man —and by extension, to all of humanity.

The man and the woman, now 'îsh and ishshâh, stand face to face with one another, poised to offer themselves as a gift to each other. They both possess intellect, will, and freedom, as well as the capacity for action and receptivity. However, their gift of self is made possible by the very differences that characterize them. Also, the gifts that each bring to the tasks of human living will be necessary to fulfil their mission, given to both of them at Genesis 1:27: to subdue the earth and fill it.

The Genesis account does reveal that it is man who, in a sense, gives woman her place. Importantly, we have seen that this place is one of "face-to-face" equality. However, her significance transcends concerns for equality. For it is woman who reveals man to himself and, with that, the meaning of human life itself. Only with the appearance of woman does man's self-gift become possible; and only with woman's arrival does human community appear for the first time-and enter into human history.

90 As St. Thomas himself argues, woman is as necessary to creation as the male of the species (Aquinas 1947, I, 92, sed contra). Thus, woman cannot be thought of as a creature whose place in that order is subservient or somehow less in stature than that of man.

91 This point is also made by Joseph Cardinal Ratzinger in his 2004 "Letter to the Bishops of the Catholic Church on the Collaboration of Men and Women in the Church and in the World," when he points out that "the term here does not refer to an inferior, but to a vital helper." See in particular Footnote \#5. I am using the word "servant" here as it is usually meant-as someone who occupies a lower rung on the ladder in any particular context. A different interpretation of the word servant is associated with being a follower of Christ, which, at this point in salvation history, cannot be invoked. However, I do not mean to imply that woman is not to serve man. As St. Paul says in Ephesians 5, both men and women are to submit to one another out of reverence for Christ. The question of the headship of the man in the family is not under scrutiny here and is a topic for further research.

92 Excellent examples can be found in the Psalms: e.g., Psalm 30: 11b, "The LORD will be a helper ('ezer) to me", or Psalm 121: 1, "I will lift up my eyes to the mountains, whence comes my help ("ezrî)." The name of the great scribe "Ezra" of the restoration of Israel under the Persians, namesake of the biblical book, seems to be the Aramaic masculine form of the same word.

93 In his very fine translation of these texts, Robert Alter translates ezer negdo as "sustainer" rather than helper, a word with a much closer meaning to that intended by the sacred author in my opinion. The author refers here to "helper" since that is the more traditional term used in most translations and makes my dispute with the usual interpretation more precise. 
Woman has sovereign importance, not independently of the place man occupies, but apart from it. For the simple fact is that without woman, man has no future. As St. Paul declares in 1 Cor 11:12, "For just as woman came from man, so man is born of woman; but all things are from God." It is this cosmic reality that has been over-looked throughout the centuries; it reveals the import of woman's "place." For in fact, without her, none of us have a future. She points us toward what is above while we all engage in life here below.

Woman and man now are both redeemed and free to serve as partners in the great project of building a truly human civilization, ordered as it is toward eternal life with the God who created them.

\section{Conclusions: Complementarity as Mission}

This paper has sought to offer critical intellectual support to feminists of all stripes by "rewriting" the history of the question of woman from within the framework of Catholic theology and the insights it contains. Hidden in the background of this approach has been St. John Paul II's own conviction that "[t]he condition that will assure the rightful presence of woman in the Church and in society is a more penetrating and accurate consideration of the anthropological foundation for masculinity and femininity with the intent of clarifying woman's personal identity in relation to man ... "94.

A premise has been that all women will benefit from recognizing the ancient origins of their struggle to assume their rightful place in society. They have been fighting an unseen enemy, who, at least in theory, has now been disarmed. Aristotle's own philosophical categories, appropriated by St. Thomas Aquinas, have now themselves been leveraged to settle the same ancient dispute that he himself began. We have diagnosed the problem and demonstrated what most of us instinctively already knew: Man and woman are equally human, equal in dignity and value; for woman's noble place derives as well directly from God and not from man. We have firmly established that neither man nor woman alone is the prime analogue for what it means to be human.

Further, contrary to previous accounts, we have seen that a proper interpretation of Scripture leads to only one possible conclusion: That woman is not inferior to man, nor is she superior to him. On the contrary, we are now able to say that she occupies a place in the created order that both complements and provides a desperately needed counterweight to that of man. Woman's appearance in creation reveals to man who he is and who or what he is for. For it is woman who introduces human community into human history, revealing its meaning and its telos.

Indeed, perhaps we could say, along with John Paul II, that woman's orientation toward the other may be the particular gift that woman brings to the world..$^{95}$ It is a gift that provides critically necessary ballast in a world in which blind ambition and the desire for material success and power often supersede concerns for the human community. Human experience "on the ground" does seem to illuminate woman's task. She is to be a constant reminder that the existence of living persons cannot be forgotten while we frantically engage in the tasks of human living. Indeed, wherever woman works, whether that be in the home or outside of it, in whatever profession she finds herself, in addition to her competence in human endeavors, woman is often the one who reminds us that all human activity is to be ordered toward authentic human flourishing. One cannot make of oneself a gift to a bottom line, a clean home-or even an academic paper. Such pursuits, while legitimate, cannot reciprocate, cannot share in such a gift. The only worthy recipient of the gift of self is another self.

Finally, though it must be admitted that Catholic teaching on this subject has contained mistakes, we have seen that the Church's affirmation of the differences between man and woman can be acknowledged without compromise to woman's essential ontological equality. From this new starting place, it is possible to articulate a feminism that is completely in accord with magisterial teaching by relying on categories that are themselves part of the fabric of the Catholic tradition. One possible

94 (John 1998, p. 50).

95 (John 1988, p. 30). 
account has been articulated here, and while it may not satisfy the criticisms of the Catholic intellectual tradition that flow from some of the waves of feminism, it may at least offer an alternate exegesis from that of Philo and others who followed his lead. It may at least demonstrate that any attempt to construe woman as inferior to man because she is created "second" in the order of creation, laid out in the sacred texts shared by Jews and Christians, is not consistent with a scholarly analysis of the original Hebrew or with the best contemporary Catholic theological anthropology. A valid theory of man and woman must seek to affirm unequivocally both sexual equality while confidently acknowledging sexual difference. That is, it must include an adequate account of both the principle of equal dignity and that of significant differentiation. This paper has been an attempt to honor those criteria. However, above all, it has been an attempt to honor woman, to restore her to her noble place in the order of creation.

Funding: This research received no external funding.

Conflicts of Interest: The author declares no conflict of interest.

\section{References}

Allen, Prudence, Sr. 1985. The Concept of Woman, Vol I: The Aristotelian Revolution. Grand Rapids: Wm. B. Eerdmans Publishing Co.

Allen, Prudence, Sr. 2002. The Concept of Woman Vol II: The Early Humanist Reformation, 1250-1500. Grand Rapids: Wm. B. Eerdmans Publishing Co.

Allen, Prudence, Sr. 2006. Man-Woman Complementarity: The Catholic Inspiration. Logos: A Journal of Catholic Thought and Culture 9: 87-108. [CrossRef]

Allen, Prudence, Sr. 2016. The Concept of Woman, Vol III: The Search for Communion of Persons, 1500-2015. Grand Rapids: Wm. B. Eerdmans Publishing Co.

Aquinas, Thomas. 1947. Summa Theologiae. New York: Benzinger Brothers, Inc.

Aquinas, Thomas. 1952. De Veritate. Chicago: Henry Regnery Company.

Aquinas, Thomas. 1968. De Ente et Essentia, 2nd ed. Translated by Armand Maurer. Rome: Pontifical Council for Medieval Studies.

Aquinas, Thomas. 2014. Summa Contra Gentiles. London: Aeterna Press.

Aristotle. 1937. Parts of Animals. Cambridge and London: Harvard Press and William Heinemann.

Aristotle. 1941. "Metaphysics" and "Topics, Sophistical Refutations and Rhetoric". In The Basic Works of Aristotle. Edited by Richard McKeon. New York: Random House.

Aristotle. 1943. The Generation of Animals. Edited and translated by Arthur Leslie Peck. Cambridge and London: Harvard University Press and William Heinemann Ltd.

Atkinson, Joseph. 2014. Biblical and Theological Foundations of the Family. Washington, DC: Catholic University Press. Botterweck, G. Johannes, Helmer Ringgren, and Heinz-Josef Fabry. 2003. Theological Dictionary of the Old Testament. Grand Rapids: Wm. B Eerdmans Publishing Co.

Butler, Judith. 1990. Gender Trouble: Feminism and the Subversion of Identity. New York: Routledge.

Butler, Judith. 1993. Bodies that Matter on the Discursive Limits of Sex. New York: Routledge.

Childs, Brevard. 1985. Old Testament Theology in a Canonical Context. Philadelphia: Fortress Press.

Combs, Mary Beth. 2005. "A Measure of Legal Independence": The 1870 Married Women's Property Act and the Portfolio Allocations of British Wives. The Journal of Economic History 65: 1028-57. [CrossRef]

Cortest, Luis. 2017. Philo's Heirs: Maimonides and Thomas Aquinas. Boston: Academic Studies Press.

de Fraine, Jean. 1965. Adam and the Family of Man. Staten Island: Alba House.

Engels, Frederic. 1884. Origins of the Family, Private Property, and the State. London: Penguin Classics. Available online: https://www.marxists.org/archive/marx/works/1884/origin-family/ch02d.htm (accessed on 15 September 2020).

Finley, John. 2015. The Metaphysics of Gender: A Thomistic Approach. The Thomist: A Speculative Quarterly Review 79: 585-614. [CrossRef]

Friedan, Betty. 1963. The Feminine Mystique. New York: W.W. Norton \& Co.

Jessel, David, and Anne Moir. 1991. Brain Sex: The Real Difference between Men and Women. New York: Dell Publishing. John, Paul, II. 1988. Mulieris Dignitatem. Rome: Libreria Editrice Vaticana.

John, Paul, II. 1995. Letter to Women. Washington: USCCB Publishing. 
John, Paul, II. 1998. Christifideles Laici. Madrid: SAN PABLO.

John, Paul, II. 2006. Man and Woman He Created Them: The Theology of the Body. Edited by Michael Waldstein. Boston: Pauline Books \& Media.

Rebecca Jordan-Young. 2010. Brainstorm. Cambridge: Harvard University Press.

Kingma, Boris, and Wouter van Marken Lichtenbelt. 2015. Energy Consumption in Buildings and Female Thermal Demand. Nature Climate Change 5: 1054-56. Available online: https://www.nature.com/articles/nclimate2741. epdf (accessed on 3 August 2015). [CrossRef]

Konner, Melvin. 2015. Women after All: Sex, Evolution, and the End of Male Supremacy. New York: W. W. Norton.

Lévy, Carlos. 2018. Philo of Alexandria. In The Stanford Encyclopedia of Philosophy. Edited by Edward N. Zalta. Stanford: Metaphysics Research Lab., Available online: https://plato.stanford.edu/archives/spr2018/entries/ philo/ (accessed on 5 February 2018).

Mill, John Stuart. 1997. The Subjection of Women. New York: Dover Publications.

Pedersen, Johaness. 1959. Israel: Its Life and Culture. London: Oxford University Press.

Philo. 1929-1962. Supplement I: Questions and Answers on Genesis. Translated by Ralph Marcus. Cambridge and London: Harvard University Press and William Heinemann, Ltd.

Plato. 1961. The Republic. In The Collected Dialogues of Plato. New York: Pantheon Books.

Rhoades, Steven E. 2004. Taking Sex Differences Seriously. San Francisco: Encounter Books.

Robinson, H. Wheeler. 1967. Corporate Personality in Ancient Israel. Philadelphia: Fortress Press.

Savage, Deborah. 2014. The Nature of Woman in Relation to Man: Genesis 1 and 2 through the Lens of the Metaphysical Anthropology of Thomas Aquinas. Logos: A Journal of Catholic Thought and Culture. Available online: https://www.questia.com/read/1G1-394999566/the-nature-of-woman-in-relation-to-man-genesis-1 (accessed on 15 September 2020). [CrossRef]

Scholer, David. 1993. The Works of Philo. Translated by C. D. Yonge. Peabody: Hendrickson Publishing.

Siglioto, Serena. 2019. Rejecting Toxic Masculinity Isn't an Attack on Men. The Journal of the Witherspoon Institute, January. Available online: https://www.thepublicdiscourse.com/2019/01/48967/ (accessed on 27 January 2019). Sly, Dorothy. 1990. Philo's Perception of Women. Atlanta: Scholars Press.

Wojtyla, Karol. 1993. Person and Community: Selected Essays. New York: Peter Lang.

(C) 2020 by the author. Licensee MDPI, Basel, Switzerland. This article is an open access article distributed under the terms and conditions of the Creative Commons Attribution (CC BY) license (http://creativecommons.org/licenses/by/4.0/). 